\title{
PERBANDINGAN AKURASI METODE FUZZY TIME SERIES DAN EKSPONENSIAL GANDA BROWN PADA PERAMALAN TINGKAT SUKU BUNGA BANK INDONESIA
}

\author{
Rita Ningsih dan Wulan Anggraeni \\ Dosen Program Studi Pendidikan Matematika Universitas Indraprasta PGRI \\ Email: ritaningsih.unindra@gmail.com
}

\begin{abstract}
Abstrak
Tujuan dari penelitian ini adalah untuk mengetahui manakah tingkat akurasi yang lebih baik antara metode fuzzy time series dibandingkan metode pemulusan ganda brown. Data yang digunakan dalam penelitian ini adalah data tingkat suku bunga Bank Indonesia yang diterbitkan oleh Bank Indonesia setiap bulannya. Periode yang digunakan dimulai dari bulan Januari 2011 sampai dengan bulan Mei 2016. Setelah dilakukan perhitungan tingkat kesalahan fuzzy time series Hsu sebesar $2.05 \%$, sedangkan tingkat kesalahan metode pemulusan ganda brown's adalah sebesar $1,36 \%$. Berdasarkan hasil perhitungan di atas dapat ditarik kesimpulan bahwa, tingkat kesalahan peramalan tingkat suku bunga menggunakan metode pemulusan ganda brown lebih kecil dibandingkan metode fuzzy time series. Sehingga di sarankan dalam meramalkan tingkat suku bunga, metode eksponensial ganda brown dapat dipergunakan.

Kata Kunci: Tingkat suku bunga, fuzzy, fuzzy time series hsu, holt double exponential smoothing.
\end{abstract} JEL Clasification : C01, C40, C53.

\section{PENDAHULUAN}

Investasi adalah suatu kegiatan menempatkan uang atau dana yang dimiliki saat ini, dengan harapan untuk memperoleh tambahan atau keuntungan tertentu atas uang atau dana tersebut di masa yang akan datang. Salah satu faktor yang mempengaruhi investasi adalah tingkat suku bunga. Di Indonesia tingkat suku bunga mengacu pada BI Rate. BI rate adalah suku bunga kebijakan yang ditetapkan oleh Bank Indonesia dan diumumkan kepada publik. Menurut Atmaja dalam Langi dkk (2014: 46) perubahan BI rate akan mempengaruhi beberapa variabel makroekonomi yang kemudian diteruskan kepada inflasi. Selanjutnya Langi dkk menyatakan bahwa perubahan berupa peningkatan level BI rate bertujuan untuk mengurangi laju aktifitas ekonomi yang mampu memicu inflasi.

Pada saat level BI rate naik maka suku bunga kredit dan depositopun akan mengalami kenaikan. Ketika suku bunga deposit naik, masyarakat akan cenderung meyimpan uangnya di bank dan jumlah uang yang beredar berkurang. Pada suku bunga kredit, kenaikan suku bunga akan merangsang para pelaku usaha untuk mengurangi investasinya karena biaya moda semakin tinggi. Hal demikianlah yang meredam aktivitas ekonomi dan pada akhirnya mengurangi tekanan inflasi. 


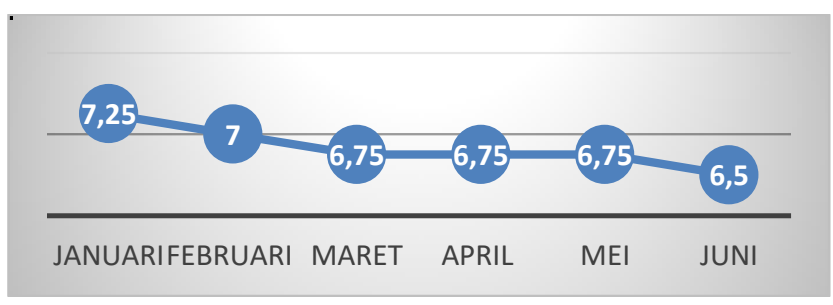

Sumber: www.Bi.go.id

Gambar 1. Tingkat suku bunga Bank Indonesia tahun 2016

Pada bulan Januari 2016, BI rate sebesar 7.25. Pada bulan Februari BI rate mengalami penurunan sebesar 0.25 point, sehingga besarnya 7 . Hal ini pun terjadi pada bulan maret. Pada bulan maret penurunan BI rate sebesar 0.25 point, sehingga besarnya 6.75. Hal ini dilakukan oleh pihak BI, dikarenakan beberapa alasan. Alasan pertama adalah agar mendorong pertumbuhan kredit dengan menjaga liquiditas perekonomian. Alasan kedua adalah dengan kombinasi penurunan suku bunga dan peningkatan likuiditas, maka tranmisi kebijakan moneter akan lebih kuat dan cepat. Alasan ketiga adalah hal ini merupakan bagian dari bauran kebijakan untuk mendorong pertumbuhan dengan tetap menjaga stabilitas. Pada bulan April dan Mei, BI mempertahankan BI rate sebesar 6.75. Sedangkan pada bulan Juni terjadi penurunan BI rate sebesar 0.25 point, sehingga besarnya BI rate pada bulan Juni sebesar 6.5.

Naik turunnya BI rate berpengaruh terhadap keadaan perekonomian. Dengan adanya suatu metode peramalan BI rate yang memiliki tingkat akurasi tinggi, diharapkan bagi para investor dan pelaku bisnis dapat membuat keputusan terbaik dalam menyimpan dana yang dimiliki. Dalam penelitian ini akan digunakan metode fuzzy time series Chen dan Hsu, dan menggunakan pemulusan eksponensial ganda brown.

Fuzzy time series (FTS) adalah sebuah konsep yang diusulkan oleh Song dan Chisom berdasarkan teori fuzzy set dan konsep variabel linguistik dan aplikasi yang dikembangkan oleh Zadeh (Nugroho, 2016: 49). Kelebihan dari metode ini adalah dapat memformulasikan suatu permasalahan yang hanya didasarkan pada pengetahuan para ahli di bidangnya atau yang didasarkan pada data empiric (Abadi dan wutsqa, 2012: 3). Metode FTS menangkap pola data dari data sebelumnya untuk meramalkan kejadian yang akan datang. Metode FTS yang digunakan dalam penelitian ini adalah metode FTS Chen dan Hsu. Secara singkat, cara kerja Metode ini adalah mendefinisikan himpunan semesta. Langkah 
ke-2 yakni mengurutkan selang interval. Langkah ketiga adalah proses fuzzifikasi/ Langkah ke-4 adalah menentukan fuzzy logical relationship. Langkah ke-5 adalah defuzzifikasi. (Chen dan Hsu, 2004: 236).

Metode pembanding yang digunakan adalah metode pemulusan eksponensial ganda dari Brown. Peramalan diperoleh dengan menggunakan satu parameter pemulusan yaitu $\alpha$ (dengan nilai antara 0 dan 1). Nilai $\alpha$ perlu dioptimalkan sehingga diperoleh kombinasi terbaik di antara dua parameter tersebut (Hansun, 2016: 75).

Berdasarkan uraian di atas maka tujuan kajian ini adalah meneliti tingkat akurasi dari metode fuzzy time series dan eksponensial ganda brown pada peramalan tingkat suku bunga Bank Indonesia (BI rate).

\section{TINJAUAN PUSTAKA}

\section{Bank}

Dendawijaya (2003: 25) menyatakan bahwa bank adalah suatu badan usaha yang tugas utamanya sebagai lembaga perantara keuangan (financial intermediaries), yang menyalurkan dana dari pihak yang kelebihan dana kepada pihak yang kekurangan dana pada waktu yang ditentukan.

Rindjin (2014: 14) menyatakan bahwa fungsi bank adalah menerima berbagai bentuk simpanan dari masyarakat, memberikan kredit baik bersumber dari dana yang diterima dari masyarakat maupun berdasarkan atas kemampuannya untuk menciptakan tenaga beli baru, memberikan jasa-jasa dalam lalu lintas pembayaran dan peredaran uang.

\section{Tingkat suku bunga}

Tingkat suku bunga dibagi menjadi 2, yaitu tingkat suku bunga nominal dan tingkat suku bunga real. Menurut Mankiw (2000: 157) tingkat suku bunga nominal adalah tingkat suku bunga yang dibayar bank. Sedangkan tingkat suku bunga real adalah adalah kenaikan daya beli. Jika $i$ menyatakan tingkat bunga nominal, $r$ menyatakan tingkat bunga real, dan $\pi$ adalah tingkat inflasi, maka hubungan di antara ketiga variabel ini bisa ditulis sebagai:

$$
r=i-\pi
$$


Tingkat bunga real adalah perbedaan di antara tingkat bunga nominal dan tingkat inflasi. Jika kita mengatur persamaan di atas, maka tingkat bunga nominal adalah:

$$
i=r+i
$$

Persamaan di atas dinamakan persamaan fisher, diambil dari nama ekonom Irving Fisher. Persamaan itu menunjukan tingkat bunga bisa berubah karena dua alasan: karena tingkat suku bunga real dan inflasi.

Selain persamaan di atas, teori fisher juga mengatakan bahwa tingkat bunga nominal pada teori kuantitas menyatakan bahwa kenaikan dalam tingkat pertumbuhan uang sebesar 1 persen menyebabkan kenaikan 1 persen dalam tingkat inflasi. Menurut persamaan fisher, kenaikan 1 persen dalam tingkat inflasi sebaliknya menyebabkan kenaikan 1 persen dalam tingkat bunga nominal. Hubungan satu untuk satu antara tingkat inflasi dan tingkat bunga nominal disebut sebagai efek fisher.

Tingkat bunga di Indonesia lebih tinggi dibandingkan Negara-negara maju, hal ini terjadi dikarenakan dinamika tingkat inflasi di Indonesia menjadi penentu tingkat bunga yang berlaku di pasar. BI rate akan naik, jika inflasi mulai naik. Hal ini dikarenakan laju ekonomi saat itu dinilai terlalu cepat dan menyebabkan ketidak seimbangan. Hal sebaliknya, BI rate akan turun saat inflasi bukan lagi bahaya dan ekonomi dapat melaju lebih kencang (Difi, 2013: 3).

\section{Tingkat Suku bunga BI}

Tingkat suku bunga BI adalah suku bunga kebijakan yang mencerminkan sikap atau stance kebijakan moneter yang ditetapkan oleh Bank Indonesia dan diumumkan kepada publik (www.BI.go.id)

\section{METODE PENELITIAN}

\section{Pendekatan Penelitian}

Pendekatan penelitian yang digunakan dalam penelitian ini adalah penelitian kualitatif. Adapun jenis dan sumber data, populasi dan sampling beserta metode pengumpulan data akan diuraikan sebagai berikut: 


\section{Jenis Sumber Data}

Data yang digunakan dalam penelitian ini adalah data tingkat suku bunga Bank Indonesia yang diterbitkan oleh Bank Indonesia setiap bulannya. Periode yang digunakan dimulai dari bulan Januari 2011 sampai dengan bulan Mei 2016.

\section{Populasi dan Sampling}

Populasi yang digunakan data tingkat suku bunga di Bank Indonesia. Sampel yang digunakan data tingkat suku bunga Bank Indonesia periode januari 2011 sampai dengan Mei 2016.

\section{Metode Pengumpulan data}

Metode pengumpulan data dalam penelitian ini adalah dokumentasi yang dilakukan untuk memperoleh data tingkat suku bunga bank Indonesia dalam hal ini data yang sudah diolah dan dipublikasikan secara umum oleh Bank Indonesia.

\section{Teknik Analisis}

Teknik analisis yang dilakukan dalam penelitian ini menggunakan data fuzzy time series dan Holt double Exponential Smoothing. Berikut ini adalah uraian dari kedua langkah metode tersebut.

\section{Metode fuzzy time series}

Metode fuzzy time series yang dipergunakan dalam penelitian ini adalah metode fuzzy time series yang dikembangkan oleh Chen dan Hsu (Chen \& Hsu, 2014: 236-240). Berikut ini adalah langkah-langkah dari metode fuzzy time series.

\section{Mendefinisikan himpunan semesta}

Himpunan semesta $U=\left[D_{\min }, D_{\text {max }}\right]$ ditentukan sesuai data historis yang ada membaginya menjadi sejumlah ganjil sub-interval dengan lebar interval yang sama besar.

\section{Mengurutkan selang interval}

Menghitung frekuensi kemunculan data dari setiap interval yang telah terbagi kemudian urutkan interval dari frekuensi yang tinggi ke rendah. Interval yang memiliki frekuensi kemunculan data tertinggi dibagi menjadi 4 sub interval, tertinggi kedua dibagi menjadi 3 sub interval, tertinggi ketiga dibagi menjadi 2 subinterval. 


\section{Proses Fuzzifikasi}

Jika $A$ adalah himpunan fuzzy, maka $A_{1}, A_{2}, A_{3}, \ldots, A_{k}$ merupakan bilanganbilangan fuzzy yang variabel linguistiknya ditentukan sesuai dengan keadaan semesta, dimana $k$ adalah jumlah interval yang didapatkan dari langkah pertama kemudian bilangan-bilangan fuzzy tersebut didefinisikan menurut model berikut ini:

$$
A_{k}=\left\{\begin{aligned}
\frac{1}{u_{1}}+\frac{0,5}{u_{2}}, & k=1 \\
\frac{0,5}{u_{k-1}}+\frac{1}{u_{k}}+\frac{0,5}{u_{k+1}}, & 2 \leq k \leq n-1 \\
\frac{0,5}{u_{n-1}}+\frac{1}{u_{n}}, & k=n
\end{aligned}\right.
$$

Keterangan:

$\frac{x}{u_{k}}: x$ merupakan derjat keanggotaan interval $u_{k}$ dalam bilangan fuzzy $A_{k}$

$u_{k}:$ sub-interval $k$ yang dibentuk dari interval $U$

$u_{k, j}$ : sub_interval $j$ yang dibentuk dari sub interval $u_{k}$

\section{Menentukan fuzzy logical relationship}

Membangun himpunan logika fuzzy berdasarkan tingkat suku bunga, yaitu:

$$
A_{j} \rightarrow A_{q}, A_{j} \rightarrow A_{r}, \mathrm{dst}
$$

Dimana relasi logika fuzzy " $A_{j} \rightarrow A_{q}$ " memiliki arti bahwa jika tingkat suku bunga pada tahun $n-1$ adalah $A_{j}$, maka tingkat suku bunga pada tahun ke $n$ adalah sebesar $A_{q}$.

\section{Proses defuzifikasi}

Proses defuzifikasi memiliki beberapa aturan yaitu:

a. Untuk data pada tahun $i=1$ (tahun pertama)

Tidak mendapatkan hasil dikarenakan tidak ada tahun sebelumnya

b. Untuk data pada tahun $i=2$ (tahun kedua)

Menghitung middle value (nilai di $\frac{1}{2}$ panjang interval) dari interva pada tahun tersebut. 
c. Untuk data pada tahun $i=3$

Menghitung $P: P=\frac{1}{2} \times\left|R_{i-1}-R_{i-2}\right|$, di mana $R_{i}$ menyatakan data pada tahun ke- $i$, kemudian menghitung $Q: Q=$ setengah panjang interval dari data. Jika $\quad P>Q \quad$ maka perhitungan prediksinya akan upward 0,75 point (nilai di $\frac{3}{4}$ panjang interval). Jika $P=Q$ maka perhitungan prediksinya akan middle value. Jika Jika $P<Q$ maka perhitungan prediksinya akan downward 0,25 point (nilai di $\frac{1}{4}$ panjang interval).

d. Untuk data pada tahun $i=4,5, \ldots, n$

Menghitung $W: W=\left(|| R_{i-1}-R_{i-2}|-| R_{i-2}-R_{i-3}\left|+R_{i-1}\right| \times 2\right.$

Menghitung $X: X=R_{i-1}-\left(|| R_{i-1}-R_{i-2}|-| R_{i-2}-R_{i-3}|| \times 2\right)$

Menghitung $Y: Y=\frac{\left(\left|\left(\left|R_{-}(i-1)-R_{-}(i-2)\right|-\left|R_{-}(i-2)-R_{-}(i-3)\right|+R_{-}(i-1)\right)\right|\right.}{2}$

Menghitung $Z: Z=R_{i-1}-\frac{\left.\left(|| R_{i-1}-R_{i-2}|-| R_{i-2}-R_{i-3}||\right)\right)}{2}$

Jika $W$ atau $X$ masuk ke dalam interval data maka perhitungan prediksinya akan upward 0,75 point. Jika $Y$ atau $Z$ masuk ke dalam interval data maka perhitungan prediksinya akan downward 0,25 point. Jika $W, X, Y$ dan $Z$ tidak ada yang masuk ke dalam interval data maka perhitungan prediksinya akan middle value.

e. Untuk data pada tahun dengan nextstate yang belum diketahui (D) menghitung middle value interval pada data nilai fuzzy dari current state.

\section{Metode Eksponensial Ganda Brown}

Persamaan yang digunakan dalam pemulusan linear satu parameter ditunjukkan sebagai berikut:

$$
\begin{aligned}
& S_{t}^{\prime}=\alpha x_{t}+(1-\alpha) S_{t-1}^{\prime} \\
& S_{t}^{\prime \prime}=\alpha S_{t}^{\prime}+(1-\alpha) S_{t}^{\prime \prime} \\
& a_{t}=S_{t}^{\prime}+\left(S_{t}^{\prime}-S_{t}^{\prime \prime}\right)=2 S_{t}^{\prime}-S_{t}^{\prime \prime} \\
& b_{t}=\frac{\alpha}{1-\alpha}\left(S_{t}^{\prime}-S_{t}^{\prime \prime}\right) \\
& F_{t}=a_{t}+b_{t} m_{t}
\end{aligned}
$$

Dimana:

$S^{\prime}(t) \quad=$ Nilai pemulusan eksponensial tunggal 
Research and Development Journal Of Education

Vol. 5 No. 1 Oktober 2018

ISSN 2406-9744

$S_{t}^{\prime \prime} \quad=$ Nilai pemulusan eksponensial ganda

$m \quad$ = Jumlah periode kedepan yang diramalkan

$F_{t+m} \quad=$ Ramalan $m$ periode ke depan

Agar dapat menggunakan persamaan di atas, nilai $S_{t-1}^{\prime}$ dan $S_{t-1}^{\prime \prime}$ harus ada. Tetapi pada saat $t=1$, nilai-nilai tersebut tidak tersedia. Jadi, nilai-nilai ini harus ditentukan pada awal periode. Hal ini dapat dilakukan dengan hanya menetapkan $S_{t}^{\prime}$ dan $S_{t}^{\prime \prime}$ sama dengan $X_{t}$ atau dengan menggunakan suatu nilai rata-rata dari beberapa nilai pertama sebagai titik awal. Jenis masalah inisialisasi ini muncul dalam setiap metode pemulusan (smoothing) eksponensial. Jika parameter pemulusan $\alpha$ tidak mendekati 0 , pengaruh dari proses inisialisasi ini dengan cepat menjadi kurang berarti dengan berlalunya waktu. Tetapi jika $\alpha$ mendekati nol, proses inisialisasi tersebut dapat memainkan peran yang nyata selama periode ke depan yang panjang. (Hansun, 2016: 75).

\section{Perhitungan kesalahan prediksi}

Pengukuran kesalahan peramalan menggunakan nilai MAPE (mean persentage absolute error)

$M A P E=\frac{\sum_{t=1}^{n} \frac{\left|Y_{t}-\widehat{Y}_{t}\right|}{Y_{t}}}{n} \times 100 \%$

(Makridaksis dkk, 1992: 43)

\section{HASIL DAN PEMBAHASAN}

Nilai parameter yang dipergunakan dalam metode pemulusan ganda brown adalah $\alpha=0,9$. Berdasarkan hasil perhitungan maka diperoleh prediksi sebagai berikut:

Tabel 1. Hasil Prediksi Tingkat Suku Bunga

\begin{tabular}{clccc}
\hline Tahun & Bulan & $\begin{array}{c}\text { Suku } \\
\text { bunga }\end{array}$ & $\begin{array}{c}\text { Prediksi } \\
\text { menggunakan } \\
\text { Metode FTS Hsu }\end{array}$ & $\begin{array}{c}\text { Prediksi } \\
\text { menggunakan } \\
\text { Metode ganda } \\
\text { brown }\end{array}$ \\
\hline \multirow{2011}{*2}{} & Januari & 6,75 & - & \\
\cline { 2 - 5 } & februari & 6,75 & 6,6875 & 6,75 \\
\cline { 2 - 5 } & Maret & 6,75 & 6,59375 & 6,75 \\
\hline & April & 6,75 & 6,78125 & 6,75 \\
\hline Mei & 6,75 & 6,78125 & 6,75 \\
\hline
\end{tabular}




\begin{tabular}{|c|c|c|c|c|}
\hline & Juli & 6,75 & 6,78125 & 6,75 \\
\hline & Agustus & 6,75 & 6,78125 & 6,75 \\
\hline & September & 6,75 & 6,78125 & 6,75 \\
\hline & Oktober & 6,5 & 6,78125 & 6,75 \\
\hline & Nopember & 6 & 6,1875 & 6,3 \\
\hline & Desember & 6 & 6,125 & 5,56 \\
\hline \multirow[t]{12}{*}{2012} & Januari & 6 & 6,125 & 5,91 \\
\hline & Februari & 5,75 & 5,875 & 5,99 \\
\hline & Maret & 5,75 & 5,875 & 5,59 \\
\hline & April & 5,75 & 5,8125 & 5,71 \\
\hline & Mei & 5,75 & 5,9375 & 5,74 \\
\hline & Juni & 5,75 & 5,9375 & 5,75 \\
\hline & Juli & 5,75 & 5,9375 & 5,75 \\
\hline & Agustus & 5,75 & 5,9375 & 5,75 \\
\hline & September & 5,75 & 5,9375 & 5,75 \\
\hline & Oktober & 5,75 & 5,9375 & 5,75 \\
\hline & Nopember & 5,75 & 5,9375 & 5,75 \\
\hline & Desember & 5,75 & 5,9375 & 5,75 \\
\hline \multirow[t]{9}{*}{2013} & Januari & 5,75 & 5,9375 & 5,75 \\
\hline & Februari & 5,75 & 5,9375 & 5,75 \\
\hline & Maret & 5,75 & 5,9375 & 5,75 \\
\hline & April & 5,75 & 5,9375 & 5,75 \\
\hline & Mei & 5,75 & 5,9375 & 5,75 \\
\hline & Juni & 6 & 6,1875 & 5,75 \\
\hline & Juli & 6,5 & 6,6875 & 6,2 \\
\hline & Agustus & 6,5 & 6,6875 & 6,94 \\
\hline & September & 7,25 & 7,34375 & 6,59 \\
\hline Tahun & Bulan & $\begin{array}{l}\text { Suku } \\
\text { bunga }\end{array}$ & $\begin{array}{c}\text { Prediksi } \\
\text { menggunakan } \\
\text { Metode FTS Hsu }\end{array}$ & $\begin{array}{c}\text { Prediksi } \\
\text { menggunakan } \\
\text { Metode ganda } \\
\text { brown }\end{array}$ \\
\hline \multirow[t]{3}{*}{2013} & Oktober & 7,25 & 7,34375 & 7,86 \\
\hline & Nopember & 7,5 & 7,484375 & 7,38 \\
\hline & Desember & 7,5 & 7,53125 & 7,72 \\
\hline \multirow[t]{10}{*}{2014} & Januari & 7,5 & 7,484375 & 7,55 \\
\hline & Februari & 7,5 & 7,765625 & 7,51 \\
\hline & Maret & 7,5 & 7,765625 & 7,50 \\
\hline & April & 7,5 & 7,765625 & 7,50 \\
\hline & Mei & 7,5 & 7,765625 & 7,50 \\
\hline & Juni & 7,5 & 7,765625 & 7,50 \\
\hline & Juli & 7,5 & 7,765625 & 7,5 \\
\hline & Agustus & 7,5 & 7,765625 & 7,5 \\
\hline & September & 7,5 & 7,765625 & 7,5 \\
\hline & Oktober & 7,5 & 7,765625 & 7,5 \\
\hline
\end{tabular}




\begin{tabular}{|c|c|c|c|c|}
\hline & Nopember & 7,5 & 7,765625 & 7,5 \\
\hline & Desember & 7,75 & 7,71875 & 7,5 \\
\hline \multirow{12}{*}{2015} & Januari & 7,75 & 7,71875 & 7,95 \\
\hline & Februari & 7,5 & 7,53125 & 7,79 \\
\hline & Maret & 7,5 & 7,53125 & 7,31 \\
\hline & April & 7,5 & 7,484375 & 7,46 \\
\hline & Mei & 7,5 & 7,578125 & 7,49 \\
\hline & Juni & 7,5 & 7,578125 & 7,50 \\
\hline & Juli & 7,5 & 7,578125 & 7,50 \\
\hline & Agustus & 7,5 & 7,578125 & 7.50 \\
\hline & September & 7,5 & 7,578125 & 7,50 \\
\hline & Oktober & 7,5 & 7,578125 & 7,5 \\
\hline & Nopember & 7,5 & 7,578125 & 7,5 \\
\hline & Desember & 7,5 & 7,578125 & 7,5 \\
\hline \multirow[t]{6}{*}{2016} & Januari & 7,25 & 7,34375 & 7,5 \\
\hline & Februari & 7 & 6,96875 & 7,05 \\
\hline & Maret & 6,75 & 6,6875 & 6,76 \\
\hline & April & 6,75 & 6,59375 & 6,50 \\
\hline & Mei & 6,75 & 6,6875 & 6,70 \\
\hline & Juni & 6,5 & 6,78125 & 6,74 \\
\hline
\end{tabular}

Sumber: BI laporan Triwulanan (berbagai tahun). Diolah kembali,

Tingkat kesalahan fuzzy time series Hsu sebesar 2,05\%, sedangkan tingkat kesalahan metode eksponensial ganda brown adalah sebesar 1,36\%. Berdasarkan hasil perhitungan di atas dapat ditarik kesimpulan bahwa, tingkat kesalahan peramalan tingkat suku bunga menggunakan metode pemulusan ganda brown lebih kecil dibandingkan metode fuzzy time series. Hasil peramalan BI rate menggunakan metode ganda brown pada bulan juli adalah sebesar 6,29. Dibandingkan dengan BI rate sebenarnya yaitu sebesar 6,5, maka terdapat selisih sebesar 0,21 .

\section{SIMPULAN}

Tingkat kesalahan fuzzy time series Hsu sebesar 2,05\%, sedangkan tingkat kesalahan metode pemulusan ganda brown adalah sebesar 1,36\%. Berdasarkan hasil perhitungan di atas dapat ditarik kesimpulan bahwa, tingkat kesalahan peramalan tingkat suku bunga menggunakan metode pemulusan ganda brown lebih rendah dibandingkan metode fuzzy time series. Keakuratan peramalan menggunakan metode pemulusan ganda brown bergantung pada nilai $\alpha$ yang kita pilih. 


\section{DAFTAR PUSTAKA}

Abadi, Agus Maman dan Wutsqa, Dhoriva Urwatul. "Optimalisasi Model Neuro Fuzzy untuk Data Time Series dengan metode dekomposisi nilai singular", Laporan Hasil Penelitian Hibah Fundamental: UNY, 2012.

Chen, Shyi Ming dan Hsu Chia-Ching. "A New Methode to Forecast Enrollments Using Fuzzy Time Series", International Journal of Applied Science and Engineering, July 2004, hal (234-244).

Dendawijaya, L. (2005). Manajemen Perbankan. Ed.2. Jakarta: Ghalia Indonesia

Langi, Theodores Manuela, Vecky Masinambow dan Hanly Siwu. "Analisis Pengaruh Bunga BI, Jumlah Uang Beredar, Dan Tingkat Kurs Terhadap Tingkat Inflasi Di Indonesia", Jurnal Berkala Ilmiah Efisiensi, Mei 2014, 14(2), hal. 44-58.

Hansun, S. (2016). “A new approach of Brown's Double Exponential Smoothing Method in Time Series Analysis", Balkan Journal of Electrical \& Computer Engineering, September 2016, hal (75-78).

http://www.BI.go.id/penjelasan-bi-rate-sebagai-suku-bunga-acuan.html diakses pada 25 Agustus 2016.

Johansah, Difi. A. (2013), Sinyal BI Rate, Newsletter Bank Indonesia, Juli, 2013, hal (1-4).

Mankiw, G. (2000), Teori Ekonomi Makro. Jakarta: PT Erlangga.

Nugroho, Kristiawan. "Model Analisis Prediksi Menggunakan Metode Fuzzy TimeSeries", Infokam, Maret 2016, XII(1), hal 46-50.

Rinjin, Ketut. (2000), Pengantar Perbankan dan Lembaga Keuangan Bukan Bank. Jakarta: Gramedia. 